
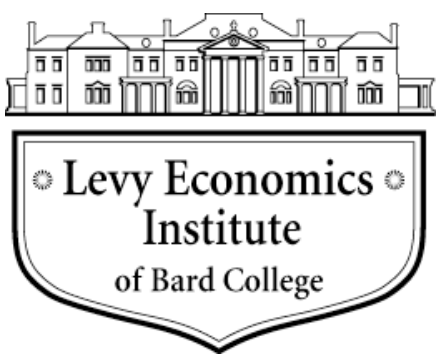

Working Paper No. 762

\title{
On the Franco-German Euro Contradiction and Ultimate Euro Battleground
}

by

\author{
Jörg Bibow* \\ Levy Economics Institute of Bard College
}

April 2013

*I thank Jerome Creel and Andrea Terzi for their comments on an earlier draft.

The Levy Economics Institute Working Paper Collection presents research in progress by Levy Institute scholars and conference participants. The purpose of the series is to disseminate ideas to and elicit comments from academics and professionals.

Levy Economics Institute of Bard College, founded in 1986, is a nonprofit, nonpartisan, independently funded research organization devoted to public service. Through scholarship and economic research it generates viable, effective public policy responses to important economic problems that profoundly affect the quality of life in the United States and abroad.

Levy Economics Institute

P.O. Box 5000

Annandale-on-Hudson, NY 12504-5000

http://www.levyinstitute.org

Copyright (C Levy Economics Institute 2013 All rights reserved

ISSN 1547-366X 


\begin{abstract}
Highlighting that France and Germany held largely contradicting hopes and aspirations for Europe's common currency, this paper analyzes how the resulting euro contradiction conditioned the ongoing euro crisis as well as current strategies to resolve it. While Germany generally prevailed in hammering out the design of the euro policy regime, the German authorities have failed to see the inconsistency in their policy endeavors: the creation of a model whose workability presupposes that others behave differently cannot be made to work by forcing everyone to behave like Germany. This fundamental misunderstanding has made Germany the main culprit in the euro crisis, but it has yet to face the full consequences of its actions. Germany had sought every protection against the much-dreaded euro "transfer union," but its own conduct has made that very outcome inevitable. Conversely, having been disappointed in its own hopes for the euro, France is now facing the prospect of a lost generation - a prospect, shared with other debtor nations in the union, that has undermined the Franco-German alliance and may soon turn it into the ultimate euro battleground.
\end{abstract}

Keywords: Currency Union; Euro Policy Regime; Euro Crisis; Franco-German Partnership; Competitiveness; ECB Policies

JEL Classifications: E02, E42, E58, E61, E65 


\section{INTRODUCTION}

Highlighting that France and Germany held largely contradicting hopes and aspirations for Europe's common currency, this paper analyzes how the resulting euro contradiction conditioned the ongoing euro crisis as well as ongoing strategies to resolve it. To France, the key issue in establishing a European monetary union was ending asymmetric adjustment pressures: The euro was to end monetary dependence, both from the vagaries of the US dollar as well as from regional deutschmark hegemony, and to establish a global reserve currency that could actually stand up to the dollar as part of a new international monetary order. By contrast, the main German concern was to forestall the threat of deutschmark strength as undermining German competitiveness within Europe. Currency overvaluation stands in conflict with Germany's export-led growth model.

In light of the euro crisis, both nations are bound to reassess the viability of the experiment. While Germany generally prevailed in hammering out the design of the euro policy regime, the German authorities until this day have failed to see the inconsistency in their policy endeavors: a model the workability of which presupposes that others behave differently cannot be made to work by forcing everyone to behave like Germany. This fundamental misunderstanding has made Germany the main culprit of the euro crisis, but Germany has yet to face the full consequences. Germany had sought every protection against the much-dreaded euro "transfer union," i.e., fiscal support of its euro partners beyond the EU budget, but its own conduct has made that very outcome inevitable. Conversely, having seen all its own hopes for the euro disappointed, France is facing the prospect of a lost generation today, a prospect shared with other debtor nations in the union and a prospect that undermines the Franco-German alliance - and one which may soon turn it into the ultimate euro battleground.

Section 2 revisits the respective economic models of France and Germany in the preEMU era stressing the currency sphere divide, followed by an analysis of how the contradicting aspirations of the two nations relate to the euro's birth defects in Section 3. While Section 4 underscores Germany's key responsibility for the divergences and related buildup of imbalances in the union that led to the euro crisis, Section 5 highlights that the crisis has created deep fault lines in the union and at its Franco-German alliance, and that France has so far accepted its diminished role as junior partner in an alliance that no longer offers much prospect of a shared future on equally agreeable terms for all sides. Section 6 argues that without a fundamental U- 
turn in German policy, it may soon be left for France to decide that breaking up the euro might be the superior alternative in containing the damages to the wider European project. Section 7 concludes.

\section{FRANCO-GERMAN ENGINE OF EUROPEAN INTEGRATION: PARTNERSHIP OF EQUALS?}

In January 2013, France and Germany celebrated the $50^{\text {th }}$ anniversary of the (Élysée) "Treaty of Friendship," marking the successful Franco-German reconciliation that transformed hereditary enemies ("Erbfeinde") into close allies in pursuit of common goals of peace and prosperity, a pivotal partnership that has also been the foremost engine of European integration. While distinct and dissimilar in many aspects of their respective ways of life, a key condition in the alliance of these two nations was that when weighing political, economic, and cultural esteem and power overall, the two partners seemed for a long time to be able to see eye to eye in their joint endeavor of building "an ever closer union of the peoples of Europe." Arguably, an overall symmetry was vital in sustaining the relationship at the heart of Europe. In light of FrancoGerman history, assurance of absence of domination had to be the lynchpin of this historical settlement. And the euro itself may be seen as both a reflection of and a tribute to the overarching need for continuous mutual trust-building and permanent disarmament of purely national powers (broadly defined). For the euro supposedly ended what had increasingly become an intolerable asymmetry: the de facto monetary reign of the Bundesbank and the deutschmark over France and Europe at large (Gros and Thygesen 1998, Reland 1998). 


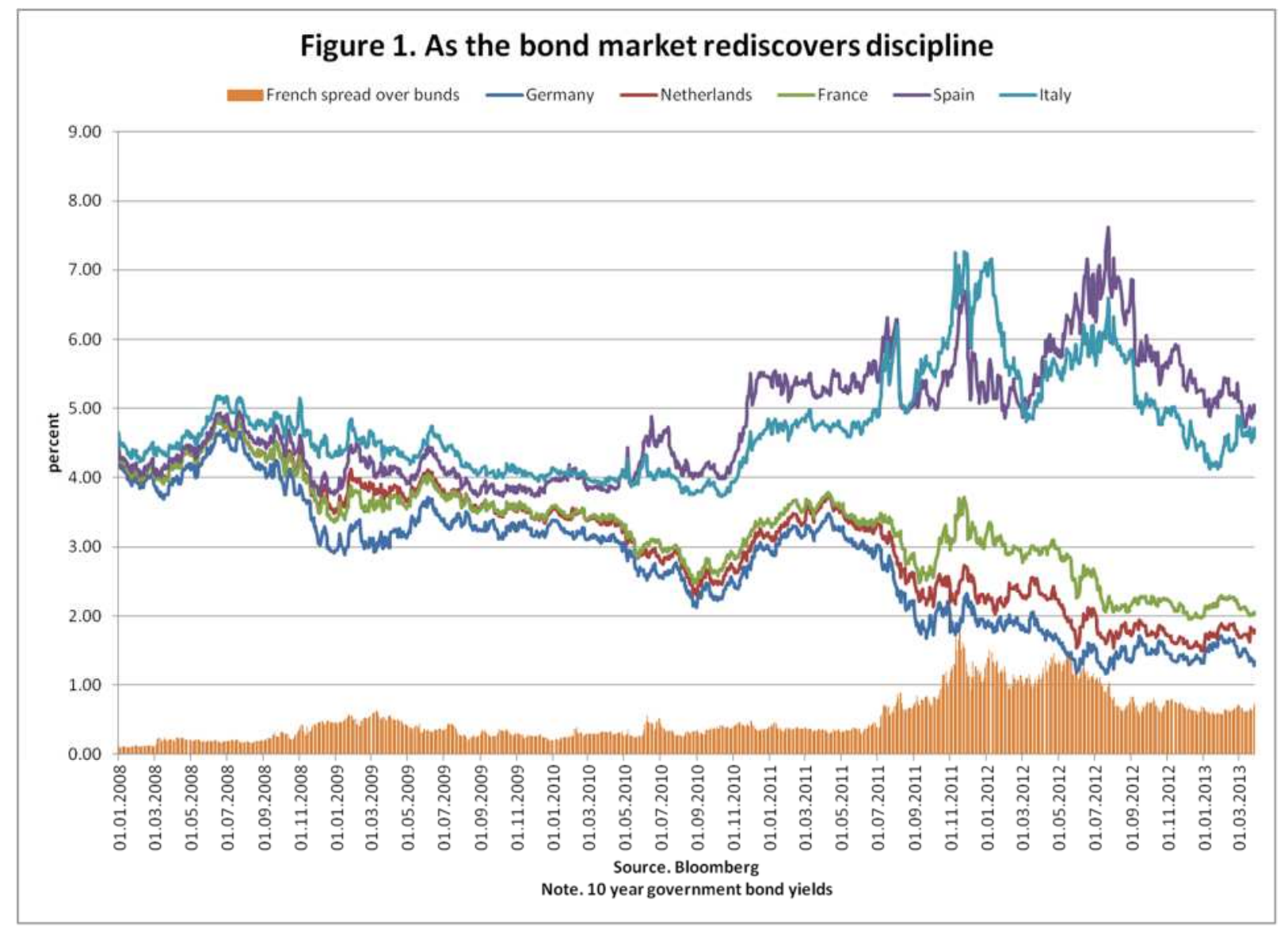

It turns out that it has not. Sovereign debt markets have provided warning signs of a reemerging asymmetry between the fall of 2011 and the summer of 2012 when yields on bundsas the sought-after safe haven—reached ever new lows, while yields on debt securities issued by the French Trésor seemed at time to move more in line with those of the so-called euro periphery (Figure 1) despite France being the other half of the supposed euro alliance. As the French spread over bonds surged in the fall of 2011 (while a sizeable French TARGET2 debit position emerged as well), the French authorities were intimidated by "market discipline" and more closely aligned their stance with German demands for unquestioned subordination to the austerity gods. In the fall of 2012, under the newly elected socialist president François Hollande, France then embarked on the supposed path of German virtue, featuring austerity, structural reform, and a collective strive for competitiveness. ${ }^{1}$ Two decades earlier, Helmut Kohl and François Mitterrand may have sincerely believed that they had eradicated an important fault line

\footnotetext{
${ }^{1}$ Hollande's campaign earlier that year featured traditional French policy preferences for pairing the stability mandate of Euroland's monetary and fiscal policies (reflecting German policy priorities) with a growth mandate.
} 
in the Franco-German partnership by establishing a common currency that was to cement their nations' ties on equal terms. Yet, in reality, Germany is still calling the shots even under the current euro regime.

The Franco-German pre-EMU asymmetry in the currency sphere had built up gradually since the last war, and Germany's success in maintaining relative price stability was critical for that outcome. Notably, it was not a harbinger of things to come but strictly a one-off event when it was first for Germany to make its experience with a national balance-of-payments crisis in 1950. Germany's crisis occurred in the context of the Korean-war boom and concomitant temporary surge in inflation, events which itself proved conducive for re-establishing Germany's position as Europe's foremost capital goods producer (Aldcroft 1993, Eichengreen 2007). For, ever since, Germany has found itself at the opposite side of balance-of-payments imbalances and resulting stresses both at the global and intra-European levels. While Germany's almost perpetual external surplus (and creditor) status has at times provoked its own inconveniences for German policymaking, France has generally found itself confronted with more fundamental challenges in this domain. Diverse national experiences in the post-war era thereby added to the memories of their respective earlier histories.

At the outset of the new Bretton Woods order, both the deutschmark and the French franc were on an equal footing in pegging to the US dollar. In the fall of 1949, shortly after the establishment of the Federal Republic of (West) Germany in May of that year, the deutschmark was pegged to the US dollar at a rate of 4.20. A trend appreciation followed, with the deutschmark reaching its highest level of 1.40 to the dollar in 1995, and a final rate of 1.67 at yearend 1998 when conversion to the euro took place. By contrast, the French franc experienced trend depreciation during this period, from a rate of 3.5 to the US dollar in the fall of 1949 to a final rate of 5.63 to the US dollar by the time of conversion into the euro. ${ }^{2}$ Correspondingly, the French franc depreciated vis-à-vis the deutschmark from 0.83 in 1949 to 3.3 in 1998. In short, as the deutschmark earned its legendary "strong" or "hard" currency status, the French franc labored under a weak currency stigma for most of the time.

These contrary currency trends also encapsulate some fundamental characteristics about the two countries' respective post-war economic history and performance. In France, the process of reconstruction and modernization followed a strategy of "indicative planning" with

\footnotetext{
${ }^{2}$ The rate at which the French franc was originally pegged to the US dollar in December 1945 was considerably stronger still, 1.19 .
} 
heavy government involvement through nationalized industries and control of credit exercised by the Trésor (enjoying power over the central bank). While France's general policy orientation (known as planification, économie concertée) included a strong preference for currency stability and protectionist reflexes, exports-rather than playing a lead role in France's post-war development — constituted the country's balance-of-payments constraint instead (Eichengreen 2007).

The Bretton Woods era saw three French franc devaluations, two towards the end of the 1950s (August 1957 and December 1958), and a third one in the late 1960s (August 1969). By that time, stress was building up in the system as inflation was on the rise and the US current account was deteriorating, augmenting global dollar liquidity, which was also a result of US capital outflows. From the French perspective, the US was abusing their "privilège exorbitant" as key reserve currency issuer. Abhorring the inherent asymmetry in the international monetary order, the French authorities started converting their rising US dollar reserves into gold.

The breakdown of the Bretton Woods order in the early 1970s ushered Europe into a state of heightened currency instability, with further humiliating experiences to follow for the French side. France made a number of attempts to participate in the "snake" arrangement that had originally been conceived as a mechanism to further narrow the fluctuation margins of intra-European exchange rates, but repeatedly had to exit under market pressures that involved the emergence of a stronger "deutschmark block." Following the period in which excessive liquidity inflows owing to the misbehavior of the global hegemon posed the key policy challenge, the French plight of being subjected to currency instability by external forces turned into one of tighter monetary stance being pursued by a newly emerging regional hegemon (James 2012).

The instabilities of the 1970s gave birth to another Franco-German initiative in the currency sphere at the end of the decade. With the objective of creating a "zone of monetary stability" and re-establishing order to Europe's monetary affairs, the European Monetary System (EMS) was a response to both global as well as European stresses. Globally, the US dollar suffered from bouts of weakness reflecting economic strains in the US, while the US administration used the G-7 forum to exert pressure on Europe, particularly Germany, to provide stimulus in support of global growth ("locomotive"). Regionally, volatile intraEuropean exchange rates posed challenges to the internal market, especially the Common Agricultural Policy. External forces augmented internal strains as dollar weakness favored the 
deutschmark over other European currencies; with the deutschmark gradually attaining reserve currency status related to the country's low inflation record and relatively open capital account. The first few years of the new "Exchange Rate Mechanism" (ERM) of the EMS thus featured numerous "realignments" and changed little compared to the earlier "snake" in practice (Gros and Thygesen 1998).

Decisive change arrived in 1983 with a U-turn in French macroeconomic policy. Having tried a more "Keynesian" response to the early 1980s recession, while Germany added austerity to tight money only to come under attack in currency markets, Mitterrand changed course and established the new "franc fort" policy instead (Reland 1998, De Boissieu and Pisani-Ferry 1999). Giving priority to stabilizing the franc-deutschmark exchange rate meant adopting Germany's macroeconomic policy stance and converging to lower German inflation. The notion of "competitive disinflation" indicates that it was understood at the time that with nominal exchange rates stabilized at the core of Europe, trends in unit-labor costs would henceforth be the decisive factor in determining intra-European competitiveness positions (Fitoussi et al. 1993). This new understanding of the competitiveness issue came on the back of the experience that currency devaluations proved rather ineffective in France, with wage rises quickly nullifying any temporary competitiveness boost. In contrast to some other European countries, including Germany, France is lacking strong corporatist traditions and has rather fractionalized labor unions.

Throughout the post-war era, France perceived the external adjustment pressures it was subjected to under evolving currency arrangements as highly asymmetric; recurrent franc devaluations bestowed spells of national humiliation upon the proud La Grande Nation. Abhorrence of US global monetary hegemony encouraged France to see virtue in regional monetary cooperation, only to find itself succumbing to external domination by the newly emerging regional hegemon: Germany.

The German post-war experience was very different. The balance of payments crisis in 1950 proved a short-lived, one-off event. External pressures to revalue the deutschmark became the norm ever after, as did internal pressures to resist a stronger currency. Resistance came mainly from Germany's increasingly export-oriented manufacturing sector, mindful of protecting its external competitiveness. In general, backing came from the government, no matter of what color, and initially even from inside the Bundesbank. The first revaluation (by 5 percent vis-à-vis the US dollar) in March 1961 followed intense battling that saw Bundesbank 
president Blessing (who had a background in German industry) fighting against revaluation while economics minister Erhard fought for it. The second revaluation in late October 1969 by 9.3 percent occurred after intense French pressure (and an earlier franc devaluation in August). The demise of the Bretton Woods order was nearing. Marking the proper start of the era of floating exchange rates, the Bundesbank ended currency market interventions in support of the dollar in early March 1973.

In contrast to France, the Bundesbank - the guardian of Germany's foreign exchange reserves - had not converted US dollars into gold at any point. This was partly for political reasons, to not undermine or alienate the external mentor and security guarantor (2012). But it was also because it was only in the early 1970s that serious threats to price stability arose for the first time since 1950. Previously, the commitment to the dollar peg was the pinnacle of the German post-war growth model that delivered an "economic miracle," featuring price stability as the foundation of prosperity through export-driven growth (Wallich 1955, Hölscher 1994, Holtfrerich 1998). The point is that with fixed nominal exchange rates, Germany experienced gradual but cumulative competitiveness gains owing to its relatively lower (2-percent) inflation trend. Strong corporatist traditions were the basis for price stability, with the Bundesbank acting as watchdog and referee. With exports as a growth engine, private domestic demand was not hindered by wage repression - though wages rising in line with productivity and the 2-percent inflation norm together made for strong investment, too. Accordingly, German public finances were in healthy shape, the occasional political strains arising when budget surpluses became too big. The model thus worked for the nation and all major interests, not least the Bundesbank that was able to establish its price stability credentials without hindering growth (Bibow 2001, 2012b).

The model unraveled in the 1970s with the collapse of Bretton Woods and the surge in wage and price inflation as well as unemployment in the aftermath of the first oil price shock (Scherf 1986). Experimentation followed, including the experience of globally coordinated macroeconomic stimulus under US pressure at the end of the decade-just in time for the arrival of another inflation surge due to the second oil price shock. The apparent encounter of a "strawfire" boom by stimulus ending with nothing but higher inflation was the decisive disillusionment with anything "Keynesian" in Germany.

Fundamental changes in German economic policy wisdom occurred in the early 1980s that were to prove highly important for Europe (and beyond) in due course. First, 
"Keynesianism" was officially banned, supply-side economics and fiscal austerity became the dogma never to be challenged. Second, never was the Bundesbank to be challenged, either, in what became its truly single-minded pursuit of price stability no matter what the labor market and wider economic situation might be. Unemployment and stagnation became-by definition - a matter of structural reform outside the domain of any macroeconomic policy consideration (Giersch, Paque, and Schmieding 1992).

While the new German dogma was to become Europe's nightmare later, it actually worked for Germany in the 1980s; it was precisely the crucial success experience that commended it as Europe's model later on. German inflation quickly declined to 2 percent early on. The public budget was balanced over the course of a decade that saw decent employment and real wage growth, supporting domestic demand as exports resumed their traditional role as the primary growth engine. This was made possible, first, by US Keynesianism of the Reagan variety (Pentagon spending plus tax cuts) with dollar strength in the first half of the 1980s, and then by cumulative competitiveness gains inside the "hardening" ERM in the second half. The French U-turn in 1983 was the decisive event for this to happen. In essence, Germany got away with its new anti-Keynesian model for reasons that were quite similar to the earlier "economic miracle" era: it only worked for Germany because others behaved differently, thereby sponsoring German export growth. In particular, for German competitiveness gains through price stability to fire the German export engine, others must have higher wage-price inflation trends. With the deutschmark serving France (and in due course other countries, too) as an anchor in their disinflation endeavors, the "hard EMS" of the 1980s provided just that. In 1989, on the eve of German unification, Germany not only had a balanced public budget, but also a large external surplus position.

German unification was a critical historical event in more than one way. Politically, the scare of a hegemonic Germany energized the push for properly locking Germany into Europe, a concern shared by Germany's chancellor at the time, Helmut Kohl. Economically, the Bundesbank showcased a crusade in "price stability only" style monetary policy. The West German economy grew at a 4-percent rate in 1988 and 1989, accelerating to 5 percent in 1990 and 1991 in the context of largely unification-related fiscal expansion that saw the balanced budget turn into a 3-percent deficit. The uptick in market-determined inflation in West Germany was minimal. But the Bundesbank made sure to throw the West German economy into deep recession while forcing fiscal austerity upon the government. On top of the legacy of a collapsed 
East German economy came the mindless wreckage caused in the west (extra 1.5 million job losses). Germany was saddled with high unemployment. Mindless austerity became the sole objective and unquestioned doctrine of German fiscal policy (Bibow 2003).

German unification also brought the last great rebalancing of Europe. The historical accident of domestic demand expansion, temporarily slightly elevated cost rises, and deutschmark appreciation in the context of the ERM crises of 1992-93 largely resolved the continent's current account imbalances. Germany had a small (around 1 percent of GDP) current account deficit in the 1990s, reflecting the East German legacy rather than any lack of competitiveness as far as the West German economy was concerned. But agreement on the "made in Germany" Maastricht regime had some rather ironic consequences. As Europe's aspirants for the German stability union converged to Germany's 2-percent stability norm, the German model stopped working for Germany. Without competitiveness gains arising from relatively lower wage-price inflation, Germany's export engine would not run as fast as it used to. This set the scene for troubles to emerge under the euro regime, to be discussed further below.

West Germany's "economic miracle" of the 1950s was partly the result of a late start from a lower level of income. Beyond that, as Table 1 summarizes, and despite their stark contrast in the currency sphere owing to divergent inflation trends, both national models worked similarly well. By the late 1980s, per capita incomes and national GDPs were at comparable levels.

\begin{tabular}{|c|c|c|c|c|c|c|c|c|c|c|c|c|c|c|}
\hline & & $1950-60$ & $1961-73$ & $1974-81$ & 1982 & 1983 & 1984 & 1985 & 1986 & 1987 & 1988 & 1989 & 1990 & 1991 \\
\hline \multirow{2}{*}{$\begin{array}{l}\text { GDP growth } \\
\text { (real, percent) }\end{array}$} & WG & 8.2 & 4.4 & 2.2 & -0.4 & 1.6 & 2.8 & 2.3 & 2.3 & 1.4 & 3.7 & 3.9 & 5.3 & 5.1 \\
\hline & \begin{tabular}{|l|}
$F$ \\
\end{tabular} & 4.6 & 5.7 & 2.7 & 2.4 & 1.2 & 1.5 & 1.6 & 2.3 & 2.4 & 4.7 & 4.2 & 2.6 & 1.0 \\
\hline \multirow{2}{*}{$\begin{array}{l}\text { CPI inflation } \\
\text { (in percent) }\end{array}$} & W G & 1.2 & 3.4 & 4.9 & 5.2 & 3.3 & 2.4 & 2.1 & -0.1 & 0.3 & 1.3 & 2.8 & 2.7 & 3.7 \\
\hline & $F$ & 6.4 & 4.6 & 11.3 & 12.0 & 9.5 & 7.7 & 5.8 & 2.5 & 3.3 & 2.7 & 3.5 & 3.5 & 3.2 \\
\hline \multirow{2}{*}{$\begin{array}{l}\text { unemployment rate } \\
\text { (in percent) }\end{array}$} & W G & 5.7 & 0.7 & 3.0 & 5.6 & 6.9 & 7.1 & 7.2 & 6.6 & 6.4 & 6.3 & 5.6 & 4.8 & 4.2 \\
\hline & $F$ & 1.5 & 2.0 & 4.6 & 7.1 & 7.1 & 8.5 & 8.9 & 9.1 & 9.3 & 8.8 & 8.4 & 8.0 & 8.4 \\
\hline \multirow{2}{*}{$\begin{array}{c}\text { population } \\
\text { (in millions) } \\
\end{array}$} & W G & 49.4 & 59.3 & 61.6 & 61.6 & 61.4 & 61.2 & 61.0 & 61.1 & 61.1 & 61.4 & 62.1 & 63.3 & 64.1 \\
\hline & $F$ & 44.4 & 50.7 & 54.7 & 55.9 & 56.2 & 56.5 & 56.7 & 57.0 & 57.3 & 57.6 & 57.9 & 58.2 & 58.5 \\
\hline \multirow{2}{*}{$\begin{array}{l}\text { budget deficit } \\
\text { (percent of GDP) }\end{array}$} & W G & 0.5 & -0.6 & -3.2 & -3.4 & -2.9 & -2.0 & -1.1 & -1.2 & $\begin{array}{l}-1.8 \\
\end{array}$ & -2.0 & 0.1 & -1.9 & -2.8 \\
\hline & $F$ & -2.7 & -0.5 & -1.2 & -2.9 & -2.6 & -2.8 & -3.1 & -3.3 & -2.1 & -2.7 & -1.9 & -2.5 & -3.0 \\
\hline \multirow{2}{*}{$\begin{array}{l}\text { gross public debt } \\
\text { (percent of GDP) }\end{array}$} & WG & 19.5 & 18.8 & 26.8 & 36.5 & 38.2 & 38.9 & 39.5 & 39.5 & 40.7 & 41.1 & 39.6 & 41.3 & 42.4 \\
\hline & \begin{tabular}{|l|}
$F$ \\
\end{tabular} & 33.4 & 18.9 & 18.3 & 25.3 & 26.6 & 29.0 & 30.6 & 31.1 & 33.4 & 33.3 & 34.0 & 35.2 & 36.0 \\
\hline \multirow{2}{*}{$\begin{array}{c}\text { openness } \\
\text { (exports+imports in \% of gdp) }\end{array}$} & W G & 21.7 & 26.6 & 36.9 & 40.5 & 40.2 & 41.9 & 43.4 & 42.7 & 43.2 & 44.0 & 46.3 & 48.9 & 51.6 \\
\hline & $\mathrm{F}$ & 12.3 & 17.3 & 25.9 & 27.5 & 27.5 & 28.5 & 28.9 & 29.1 & 29.9 & 31.0 & 32.4 & 33.0 & 34.1 \\
\hline
\end{tabular}




\section{CONSENSUS DESPITE CONTRADICTING ASPIRATIONS: THE EURO'S BIRTH DEFECTS}

The complex hurdles and potholes that had to be overcome on the long and winding "road to Maastricht," and the pivotal role played along this journey by the Bundesbank, were documented by Bernholz (1998), Dyson and Featherstone (1999), and James (2012), for instance. France was under no illusion about the fact that a currency union could only be had on German terms. In particular, the ECB had to copycat the Bundesbank, and the Banque de France was turned into a clone, as well (Kaltenthaler 1998). Squarely contradicting French traditions emphasizing the centralization of public power and primacy of politics, agreeing to the German variety of central bank independence was difficult to accept. The one aspect in which French influence was crucial concerned the setting of firm deadlines or, rather, starting dates for launching the euro: This meant that there would be no opt-out route for Germany (other than through national embarrassment by failing to meet the "convergence criteria" that had their origin in German stability dogma to be Europeanized through the Maastricht regime).

The above review of the two countries' post-war comparative performance and policy orientation indicates that the two partners entered the union with rather contradictory aspirations. To France, the key issue was ending asymmetric adjustment pressures: The euro was to end monetary dependence, both from the vagaries of the US dollar as well as from the deutschmark, and to establish a global reserve currency that could actually stand up to the dollar as part of a new international monetary order. By contrast, the main German concern was to forestall the threat of deutschmark strength as undermining German competitiveness within Europe. Currency overvaluation presented a conflict with Germany's peculiar mercantilistic trade inclination and export-led growth model. The Bundesbank had resisted the deutschmark's rising reserve currency status, which was bound to provoke conflicts with German industrialists' interests, while abhorring any constraints on its domestic stability orientation arising from external commitments, the area which used to be the most frequent source of conflict with the government (generally aligned with industry interests).

The clash of Franco-German policy traditions together with contradicting aspirations bestowed important birth defects upon the euro. United in their belief that the time for monetary union was ripe but unable to resolve fundamental Franco-German discord about economic policies, the monetary union was left incomplete and narrowly focused on the areas in which German views were nonnegotiable anyway. In particular, single-mindedly focused on price 
stability and fiscal discipline, the Maastricht regime largely neglected fundamental issues such as fiscal union and demand management, financial stability policy, exchange-rate policy, and intra-union competitiveness.

Germany had traditionally been more enthusiastic about greater political integration than France (Stephens 2012). German governments from Brandt to Kohl saw creating room for both deeper monetary as well as political integration as a quid pro quo. Kohl insisted that an intergovernmental conference on political union be held in parallel to the one on monetary union. But the substance of any German ambitions in this direction really referred to foreign policy rather than any need to establish the political foundations for fiscal union as providing a proper fiscal backing of Europe's monetary union.

While France strongly emphasized the need for a "political pole" to balance the "monetary pole," this demand really concerned the position of the all-mighty European Central Bank. From the French perspective, so much independent and unaccountable power needed to be checked by politics—by an "economic government" (controlled by national governments)— while Germany feared that any such counter-pole would represent a risk to central bank independence and price stability, apart from potentially opening the door for a "transfer union." France, at the same time, strongly opposed any loss of fiscal sovereignty along with the aspired pooling of monetary sovereignty (which, from the French perspective, meant regaining a voice in European monetary policy). Neither France nor Germany considered that monetary union might need to be supplemented by any kind of euro treasury linked to the ECB.

From the German perspective, delinking the central bank from the treasury (rather national treasuries) through prohibitions of central bank loans (or, so-called monetary financing) while leaving a treasury vacuum at the union level was even held to lend support to the (denationalized) currency and its central bank guardian (Bibow 2012b). From the French perspective, the peculiar position of the independent central bank was at odds with French traditions more for political rather than economic reasons, although, unlike Germany, France had not declared demand management and coordination of macro policies to the rank of nonissues. If anything, France seemed even more concerned about surrendering fiscal sovereignty than Germany. In the end, German fears of fiscal profligacy gave way to establishing a set of fiscal rules designed to discipline national fiscal policies without circumscribing fiscal sovereignty beyond the limits set for public deficit and debt ratios and as 
supplemented by a "no-bail-out clause" that was thought to provide a bulwark against a transfer union.

Charles Goodhart warned before the euro's launch that its designers may have paid too little attention to the existential role of the state in the currency sphere:

The key relationship in the [Cartalist] model is the centrality of the link between political sovereignty and fiscal authority on the one hand and money creation, the mint and the central bank, on the other. A key fact in the proposed euro system is that that link is to be weakened to a degree rarely, if ever, known before.

(Goodhart 1998)

His Cartalist critique of the Optimum Currency Area (OCA) theory suggests that the euro area's delinking of the central bank and the treasury is not only an exception to the "one nation, one currency" rule observed across the globe but may also represent the ultimate source of the euro area's vulnerability. The point is that this peculiar delinking mutually undermines the joint powers normally enjoyed by the treasury-central bank alliance in the currency sphere of sovereign nations, whereby the treasury is strengthened by the central bank's underwriting of liquidity while the central bank's credibility as lender of last resort, in turn, is strengthened by the treasury's "deep pockets" as fiscal backing, too.

As a branch of neoclassical monetary theory, OCA theory itself is preoccupied with transaction costs and market rigidities, issues seemingly best overcome by market liberalization and the "one market, one money" principle put in practice. The same way of thinking was applied with especially naïve neoliberal fervor to the closely related issue of financial integration. Both Germany and France had started to liberalize their financial systems in the 1980s. The Single Market Program released great new energies to that effect, including the complete liberalization of capital flows (an area in which France had lagged Germany until the 1980s; Abdelal 2007). The approaching of the single currency in the 1990s then made this argument even more compelling. And in a way it certainly does, as a fully integrated financial market is a precondition for the single monetary policy to establish largely uniform financial conditions throughout the currency union.

But the lack of fiscal union as a latent source of vulnerability reemerges here once it is acknowledged that the potential need to bail out financial institutions might require close treasury-central bank cooperation, which in the case of institutions with strong cross-border engagements and linkages comes along with additional challenges for policy coordination and burden sharing. Remarkably, in the domain of financial stability policy the EU/euro partners 
saw no need to replicate at the level of the union the "one market, one policy/authority" principle traditionally in place at the nation-state level. Essentially, Europe created the single financial market, but was satisfied with minimum standards for national financial regulators and supervisors while otherwise practicing mutual recognition (EU passport principle). This meant that financial institutions were let off the hook to roam freely in the common market (and beyond) without effective policy control. With banks facing heightened competition from deepening liberalized markets, incentives were set for adventurous excursions into new territories and innovative products.

So the ECB was established with minimal authority in this traditional central banking domain (Padoa-Schioppa 2004; James 2012). The Treaties merely mention that the ECB should "contribute to smooth conduct of policies pursued by the competent authorities relating to prudential supervision of credit institutions and the stability of the financial system" and that "specific tasks concerning policies relating to the prudential supervision of credit institutions may be conferred upon the ECB." Traditionally, the Bundesbank, too, only had a supporting role to play in this domain in Germany, with a separate financial supervisory authority (Bundesaufsichtsamt für das Kreditwesen) fulfilling the main part. This was for fear that financial stability issues might otherwise compromise monetary policy or undermine the central bank's reputation and standing. With notorious moral hazard fears dominating any other concerns, the Bundesbank never even acknowledged its role as lender of last resort (apparently outsourced to a private liquidity pooling consortium named the Liquiditäts-Konsortialbank). In Germany, unsurprisingly, strong resistance against transferring supervisory powers to the European level also came from the Bundesaufsichtsamt itself. Such resistance also existed in France and elsewhere. As a result of lacking a euro treasury, and with the ECB missing on the field as lender of last resort, any financial system rescues would need to be organized among the respective national treasuries and central banks - each however weakened by the fact that, as euro member states, they were now issuing debts denominated in what is effectively a foreign currency for each of them, the (nation-less) euro.

Another vulnerability, which also has its source in the lack of a euro treasury, concerns the domain of exchange rate policy. Traditionally, exchange rate policy falls under the authority of the treasury. This is the case today in countries such as the US, UK, and Japan. In pre-EMU times, it was also the case in France, and actually even in Germany. As a government prerogative, exchange rate policy represented the Achilles heel of the Bundesbank's "stability 
policy" and was the foremost source of conflict with the German government (see Emminger 1986, Goodman 1992, Henning 1994, and Johnson 1998). For instance, while Helmut Schmidt first negotiated the EMS without the Bundesbank sitting at the table, he afterwards acquiesced to the infamous "Emminger letter," which provided a kind of opt-out clause from the obligation for unlimited liquidity support of the EMS. In the negotiations that led to the Maastricht Treaty, the Bundesbank was adamant in making sure that the ECB would be equally, if not more, protected from any political influence in this domain (James 2012). Again, the absence of a euro treasury would seem to represent an advantage and source of strength from the Bundesbank perspective, as the treaty rules severely restrict the potential for the Council or Commission to establish any external constraints on the ECB's stability-oriented monetary policies. In practice, however, the ECB, too, is treading very carefully in these waters, probably fearing that any more conspicuous conduct might risk rekindling ambitions by the political authorities. As a result, the euro area is largely missing any proper external exchange rate policy (PadoaSchioppa 2004)—which matters when other key global players have one. ${ }^{3}$

The lack of a common (external) exchange rate policy determining the area's external competitiveness position is one thing. Perhaps the most remarkable issue is that the regime designers completely forgot about the original motivation of all their endeavors for monetary cooperation and integration: to prevent disruptive changes in intra-area competitiveness positions. This is even more remarkable given that the theme of "competitive disinflation" has played a prominent role in France since the 1980s. The issue also remained critical given that ERM membership and absence of competitive devaluation was one of the "convergence criteria" in the 1990s. The issue then disappeared from the radar screen with the euro, it seems. If that was for the apparent belief that the threat of competitive devaluation would disappear together with national currencies as soon as the euro were to take over, the euro area was in for a big surprise.

In conclusion, the euro was born with rather serious birth defects. The absence of a euro treasury, exchange rate policy, and financial stability policy as an integral part of the central banking domain may have all seemed to represent advantages from the German perspective (Bibow 2007). By contrast, France had very different ambitions in the domain of exchange rate policy and was also more positively predisposed toward active demand management and macro

\footnotetext{
${ }^{3}$ Internationally coordinated currency market interventions occurred in the fall of 2000 to halt the euro's plunge. In 2004 and 2006, ECB president Trichet applied “verbal interventions” to slow the euro's rise.
} 
policy coordination. But the idea of an economic government involved control by national governments rather than any euro treasury - the whole idea representing anathema to the German angst about the ECB's position of unchallengeable independence.

\section{SUPPOSED STABILITY GUARANTOR BREEDS INSTABILITY}

While the euro's birth defects provided the ultimate source of the currency union's vulnerability, the immediate cause of the euro crisis that has ravaged the area since 2010 turned out to be more mundane and preventable. The irony is that it was precisely Germany, the apostle of stability and supposed anchor of stability that undermined the currency union by reneging on what I elsewhere dubbed the "golden rule of currency union."

Essentially, a currency union is a commitment to a common inflation rate. The ECB's (revised) definition of price stability as "below but close to 2 percent" attaches a number to that commitment, and thereby provides a stability norm for wage trends. The golden rule of currency union says that national wage trends corrected for productivity (i.e., unit labor costs) cannot stray from this stability norm for long without causing imbalances. With nominal exchange rates gone, unit labor cost trends determine whether intra-area real exchange rates stay in balance.

The widely-held view that crisis countries lost competitiveness due to excessive wageprice inflation is missing the point. Germany was the true outlier, although in the downward direction. As Europe converged to the 2-percent stability norm and Germany's export engine sputtered, Germany diverged from its own historical 2-percent stability norm under the euro regime. One consequence was that competitiveness positions inside the currency union ran seriously out of kilter and imbalances built up. Another consequence was that diverging wage trends also undermined the "one-size-fits-all" monetary policy. At a close to 30-percent share, Germany is the largest economy in the currency union. As wage restraint together with mindless austerity and structural labor market reform depressed consumption and raised inequality in Germany, the ECB's uniform nominal interest rate also meant relatively tighter financial conditions in Germany, magnifying divergence further, as the opposite would be the case in countries with above-average inflation, such as booming and bubbling Spain and Ireland (Bibow 2006, 2012a). 


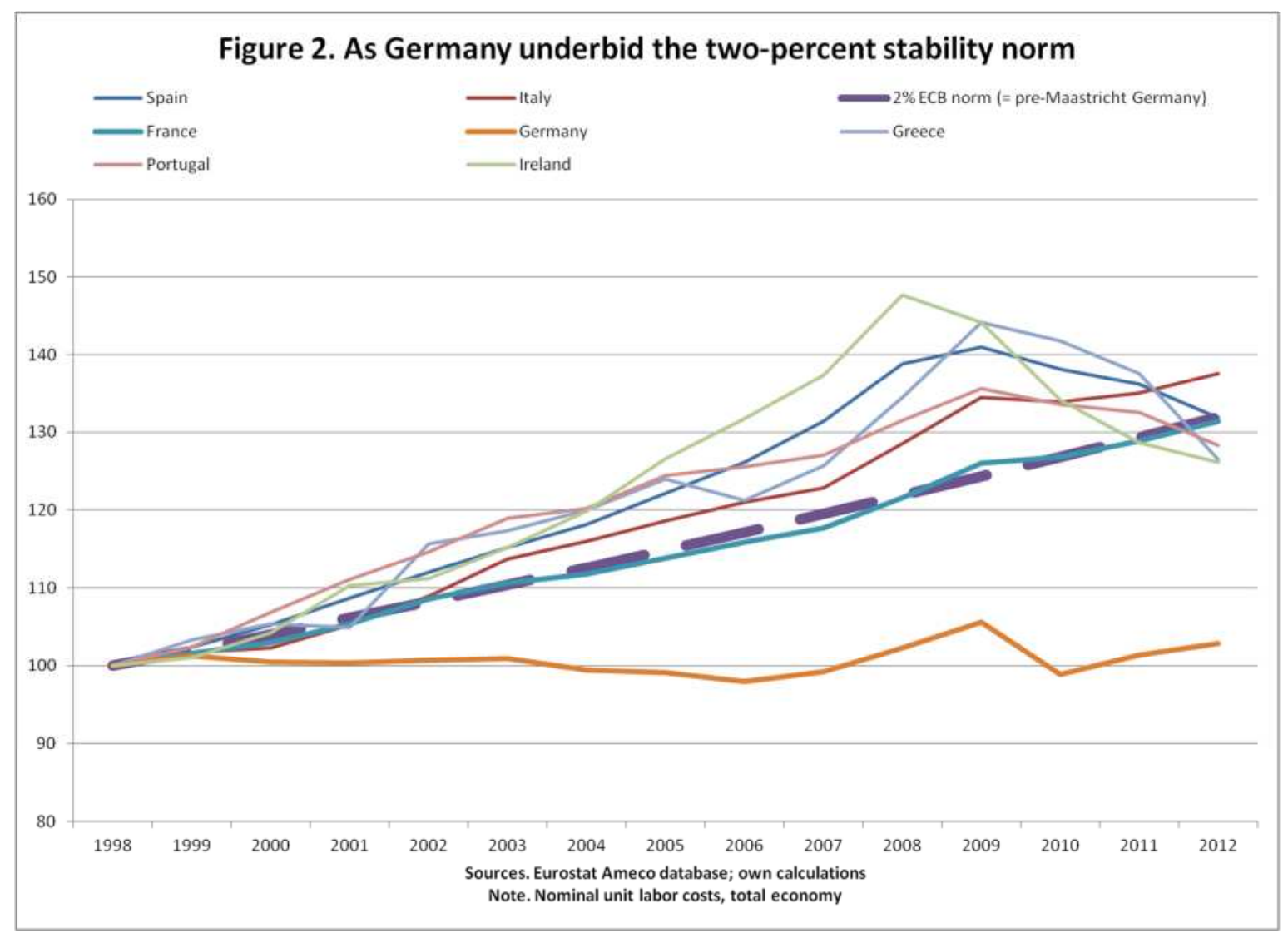

A comparison between Germany and France is especially instructive. It turns out that France was the one member country that truly stayed the course, the shared commitment to the 2-percent stability norm (see Figure 2). Both countries shared the impact of the "global slowdown" of 2001, a common shock. Yet, thereafter the performance of the two economies could hardly have been more different. In Germany, fiscal austerity, wage restraint, and structural reform combined to systematically suffocate domestic demand, both consumption and investment. Exports were Germany's sole engine of growth, perhaps temporarily sparking some corporate investment when the export stimulus turned out strong enough at times. By contrast, French growth was driven by domestic demand while net exports acted as a drag on growth; private consumption was the main engine, and housing and corporate investment played supporting roles. As German property prices were sagging, they were rising in France (albeit not at the bubbling pace of Ireland and Spain). Income distribution underwent a seismic shift in Germany, but stayed stable in France. As the German consumer suffered from manic depression and worshipped frugality, the French bon vivant saw the future more favorably; French birth rates rose while German rates declined. 
Both countries famously breached the 3-percent ceiling of the so-called Stability and Growth Pact in the aftermath of the global slowdown. Yet, while Germany's fiscal beancounters practiced collective masochism by letting net public investment turn negative (thereby reneging on their grandchildren's future), the French authorities went about public matters with more care and caution-in awareness of the fact that excessive austerity is counterproductive. The public finances of the two countries evolved in broadly parallel fashion until the global crisis struck in 2008. Germany's public deficit ratio eventually started falling faster as the global boom of the 2000s was approaching its climax, but public debt ratios moved in tandem as France had faster growth throughout (see Table 2).

\begin{tabular}{|c|c|c|c|c|c|c|c|c|c|c|c|c|c|c|c|}
\hline & & 1999 & 2000 & 2001 & 2002 & 2003 & 2004 & 2005 & 2006 & 2007 & 2008 & 2009 & 2010 & 2011 & 2012 \\
\hline \multirow{2}{*}{$\begin{array}{c}\text { GDP growth } \\
\text { (real, in percent) }\end{array}$} & $\mathrm{G}$ & 1.9 & 3.1 & 1.5 & 0.0 & -0.4 & 1.2 & 0.7 & 3.7 & 3.3 & 1.1 & -5.1 & 4.2 & 3.0 & 0.7 \\
\hline & $F$ & 3.3 & $\begin{array}{l}3.7 \\
\end{array}$ & 1.8 & 0.9 & 0.9 & 2.5 & 1.8 & 2.5 & 2.3 & $\begin{array}{l}-0.1 \\
\end{array}$ & -3.1 & 1.7 & 1.7 & 0.0 \\
\hline \multirow{2}{*}{$\begin{array}{l}\text { domestic demand growth } \\
\text { (real, in percent) }\end{array}$} & $\mathrm{G}$ & 2.6 & 2.0 & 0.2 & -1.4 & 0.0 & 0.1 & 0.3 & 2.6 & 1.1 & 1.3 & -1.6 & 2.0 & 2.4 & 0.2 \\
\hline & $\mathrm{F}$ & 3.9 & 3.7 & 2.1 & 1.2 & 1.9 & 2.1 & 2.5 & 2.4 & 3.0 & 0.5 & -1.5 & 1.5 & 0.9 & 0.3 \\
\hline \multirow{2}{*}{$\begin{array}{l}\text { private consumption growth } \\
\text { (real, in percent) }\end{array}$} & G & 2.4 & 2.0 & 1.3 & -0.6 & 0.3 & 0.4 & 0.2 & 1.5 & -0.2 & 0.8 & 0.1 & 0.9 & 1.7 & 0.8 \\
\hline & $\mathrm{F}$ & 3.4 & 3.4 & 2.4 & 2.0 & 1.7 & 1.7 & 2.5 & 2.2 & 2.4 & 0.2 & 0.3 & 1.5 & 0.3 & 0.0 \\
\hline \multirow{2}{*}{$\begin{array}{l}\text { gross capital formation } \\
\text { (percent of GDP) }\end{array}$} & $G$ & 20.7 & 20.8 & 19.5 & 17.8 & 18.1 & 17.7 & 17.3 & 18.1 & 19.1 & 19.0 & 17.0 & 17.9 & 18.7 & 17.5 \\
\hline & $\mathrm{F}$ & 18.9 & 19.8 & 19.6 & 18.8 & 18.7 & 19.5 & 20.0 & 20.3 & 21.3 & 21.2 & 18.4 & 18.4 & 19.5 & 18.5 \\
\hline \multirow{2}{*}{$\begin{array}{c}\text { net capital formation } \\
\text { (percent of GDP) }\end{array}$} & $\mathrm{G}$ & 6.4 & 6.2 & 4.9 & 3.4 & 2.9 & 2.6 & 2.5 & 3.6 & 3.9 & 3.8 & 1.5 & 2.3 & 3.1 & $\mathrm{n} / \mathrm{a}$ \\
\hline & $F$ & 8.1 & 8.4 & 8.0 & 7.0 & 6.8 & 6.7 & 6.8 & 6.9 & 7.4 & 6.8 & 4.4 & 4.2 & 4.4 & $\mathrm{n} / \mathrm{a}$ \\
\hline \multirow{2}{*}{$\begin{array}{l}\text { net public fixed capital formation } \\
\text { (euro bn) }\end{array}$} & G & 4.5 & 3.5 & 2.9 & 1.6 & -1.3 & -4.4 & -6.0 & -4.6 & -4.2 & -2.8 & -1.1 & -1.2 & -1.8 & -6.2 \\
\hline & $\mathrm{F}$ & 8.4 & 12.6 & 11.7 & 10.1 & 11.8 & 13.0 & 16.1 & 14.8 & 16.4 & 14.2 & 14.8 & 9.1 & 7.7 & 6.7 \\
\hline \multirow{2}{*}{$\begin{array}{c}\text { population } \\
\text { (millions) } \\
\end{array}$} & $\mathrm{G}$ & 82.1 & 82.2 & 82.3 & 82.5 & 82.5 & 82.5 & 82.5 & 82.4 & 82.3 & 82.1 & 81.9 & 81.8 & 81.8 & 81.9 \\
\hline & $\mathrm{F}$ & 60.4 & 60.8 & 61.2 & 61.6 & 62.1 & 62.5 & 63.0 & 63.4 & 63.8 & 64.2 & 64.5 & 64.9 & 65.2 & 65.6 \\
\hline \multirow{2}{*}{$\begin{array}{c}\text { fertility rate } \\
\text { (number of children per woman) }\end{array}$} & $\mathrm{G}$ & $\mathrm{n} / \mathrm{a}$ & 1.38 & 1.35 & 1.34 & 1.34 & 1.36 & 1.34 & 1.33 & 1.37 & 1.38 & 1.36 & 1.39 & 1.36 & $\mathrm{n} / \mathrm{a}$ \\
\hline & $F$ & 1.81 & 1.89 & 1.9 & 1.88 & 1.89 & 1.92 & 1.94 & 2 & 1.98 & 2.01 & 2 & 2.03 & 2.01 & $\mathrm{n} / \mathrm{a}$ \\
\hline \multirow{2}{*}{$\begin{array}{c}\text { unemployment rate } \\
\text { (in percent) }\end{array}$} & $\mathrm{G}$ & 8.6 & 8 & 7.9 & 8.7 & 9.8 & 10.5 & 11.3 & 10.3 & 8.7 & 7.5 & 7.8 & 7.1 & 5.9 & 5.5 \\
\hline & $\mathrm{F}$ & 10.4 & 9 & 8.2 & 8.3 & 8.9 & 9.3 & 9.3 & 9.2 & 8.4 & 7.8 & 9.5 & 9.7 & 9.6 & 10.3 \\
\hline \multirow{2}{*}{$\begin{array}{c}\text { budget deficit } \\
\text { (percent of GDP) }\end{array}$} & $G$ & -1.6 & 1.1 & -3.1 & -3.8 & -4.2 & -3.8 & -3.3 & -1.6 & 0.2 & -0.1 & -3.1 & -4.1 & -0.8 & 0.1 \\
\hline & $F$ & $\begin{array}{l}-1.8 \\
\end{array}$ & -1.5 & -1.6 & -3.3 & -4.1 & -3.6 & -2.9 & -2.3 & -2.7 & $\begin{array}{l}-3.3 \\
\end{array}$ & -7.5 & $\begin{array}{l}-7.1 \\
\end{array}$ & -5.2 & -4.6 \\
\hline \multirow{2}{*}{$\begin{array}{l}\text { gross public debt } \\
\text { (percent of GDP) }\end{array}$} & $G$ & 61.3 & 60.2 & 59.1 & 60.7 & 64.4 & 66.2 & 68.5 & 68.0 & 65.2 & 66.8 & 74.5 & 82.5 & 80.5 & 81.6 \\
\hline & $\mathrm{F}$ & 58.9 & 57.4 & 56.9 & 59.0 & 63.2 & 65.0 & 66.7 & 64.0 & 64.2 & 68.2 & 79.2 & 82.3 & 86.0 & 90.3 \\
\hline \multirow{2}{*}{$\begin{array}{c}\text { openness } \\
\text { (exports+imports as } \% \text { of GDP) } \\
\end{array}$} & $G$ & 57.2 & 62.1 & 63.5 & 64.5 & 67.3 & 72.9 & 77.4 & 84.0 & 86.9 & 88.6 & 83.5 & 90.1 & 94.2 & 96.6 \\
\hline & $\mathrm{F}$ & 46.3 & 50.7 & 51.0 & 51.4 & 50.8 & 52.1 & 53.4 & 54.7 & 55.6 & 55.8 & 51.4 & 55.2 & 57.1 & 57.6 \\
\hline \multicolumn{16}{|c|}{ Sources. Eurostat AMECO } \\
\hline
\end{tabular}

Another critical major divergence between the two partners was underway all along. As a roughly 20-percentage point differential in national unit-labor cost trends gradually built up, the two countries' external positions ran out of kilter. Germany's current account surplus surged beyond 7 percent of GDP prior to the crisis. France saw its surplus of 1-2 percent of GDP at the start of the currency union turn into a deficit of similar magnitude. The bilateral trade position of the two partners turned massively in Germany's favor over the same period, too.

Correspondingly, while Germany built up a large creditor net international investment position under the euro regime, France's net international investment position turned from creditor to debtor status. Essentially, Europe — and the France-German alliance at its core—saw a classic repeat of intra-area divergences and buildup of imbalances of the very kind that the euro was meant to ban forever. When this last happened in the course of the 1980s, German unification 
(i.e., accidental German stimulus) and the ERM crises rebalanced Europe (Figure 3). Under the euro regime, the latter is no option anymore today, while no German stimulus is in the cards either. As a result, deep fault lines are dividing the two partners today, especially as public finances, too, have parted company since 2010 and the French economic model became seriously unclenched in the course of 2012.

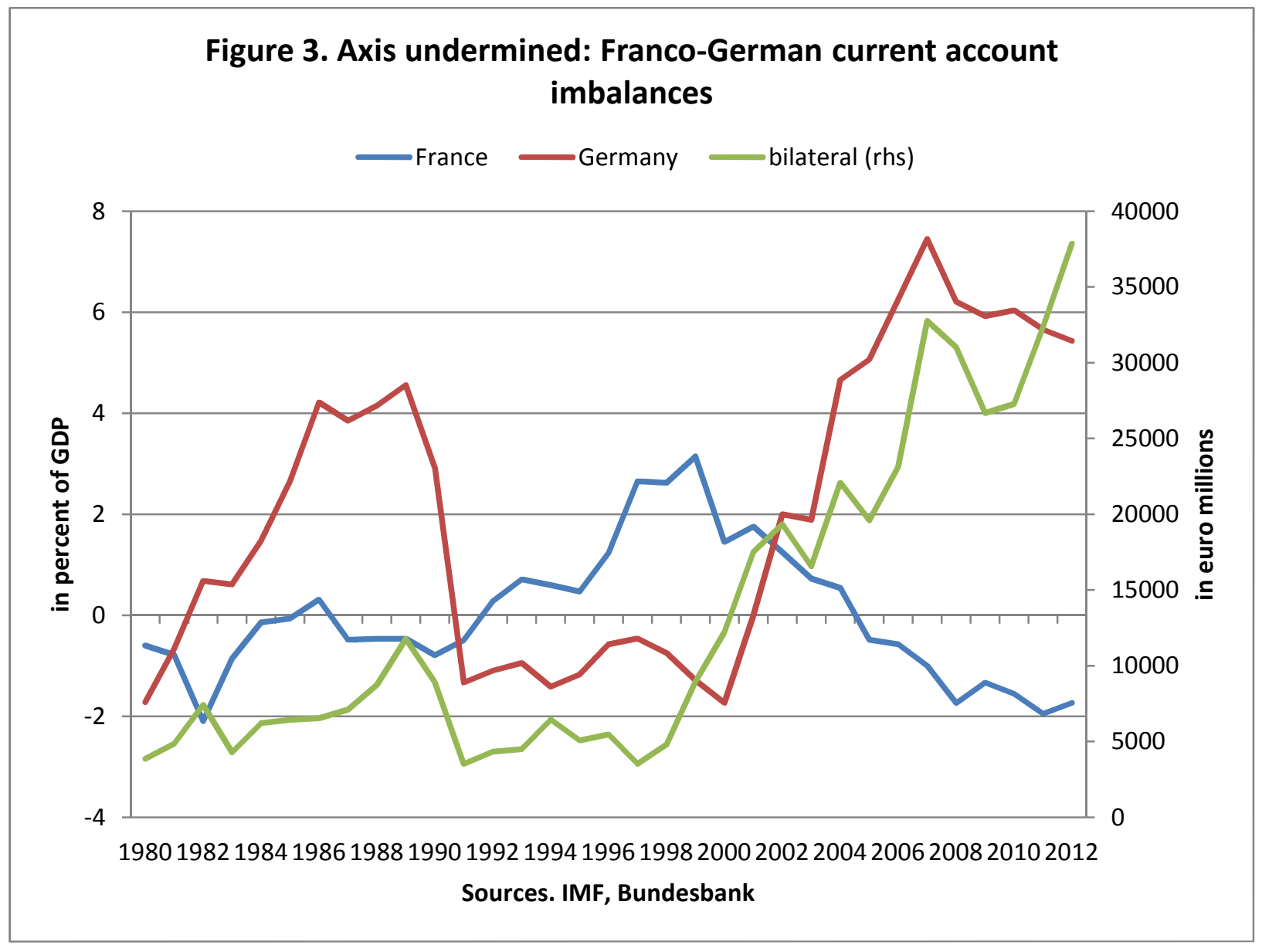

\section{FRANCO-GERMAN DISCORD AND FAULT LINES: PARTNERSHIP OF UNEQUALS AT WORK}

The euro crisis first turned ugly in the small "peripheral" economies of Greece, Ireland, and Portugal in 2010. Whether their societies will withstand further austerity-driven hardship is an open question. In principle, the quasi-fiscal joint rescue facilities (EFSF, ESM) created appear to have sufficient resources to shore up the smaller economies to prevent regional contagion. As Italy and Spain, the number 3 and 4 economies, joined the inner ring of acute crisis in 2011-12, 
it became clear that this would no longer be the case. It took the ECB's promise of liquidity support for government bond markets to convince the markets, at least temporarily, that the euro's breakup may not be imminent after all. It is important that the ECB's cherished liquidity "bazooka" will only be fired on the condition that countries carry through with fiscal austerity and structural reform - the miraculous cure-all promised to boost confidence, competitiveness, and growth. In reality, both real and nominal GDP in crisis countries continue shrinking while interest rates remain at elevated levels.

Over the course of 2012, France succumbed to the recessionary forces devastating its southern neighbors and to political pressures to converge to the German path of virtue based on structural reform and austerity. As the farce of a partnership of equals could no longer be upheld, the French authorities seem to have concluded that France has to restore its competitiveness to rise back to level with Germany. The challenge France is facing in restoring its competitiveness is symptomatic for much of the rest of the union. An analysis of the French case may serve to illustrate the futility and precariousness of the whole endeavor-and the confused German competitiveness dogma that has come to dictate policymaking in Europe's currency union.

Germany shed its title as "sick man of the euro" when the economy finally started growing on the back of the global boom in 2006-07. A surging trade surplus-including a surging bilateral surplus vis-à-vis France-allowed Germany to reach its foremost economic policy goal of balancing the public budget. Note here, then, that the German success with structural reform arose and was made possible by a global boom and the fact that other countries behaved differently, thereby sponsoring Germany's recovery and balanced budget. The crisis broke as those sponsors saw their debt bubbles implode that were the internal counterparts to their external overspending. Due to global banking linkages, the unraveling began to unfold almost simultaneously for both global (US) as well as intra-Euroland imbalances. Inevitably, given its stark export dependence, Germany was among the hardest-hit economies as the crisis struck. France, being both less export-dependent while also not subject to an imploding internal bubble either, fared better initially. Miraculously, probably realizing that the abysmal crashing of the economy at the turn of the year 2008-09 might not bode well for the federal election that was coming up in the fall of 2009 , the German authorities briefly broke with their antiKeynesian principles and implemented a sizeable fiscal stimulus together with more direct support measures for the labor market and banks. But the main reason for Germany's recovery 
from the crisis was external: the rebooting of the German export engine on the back of the US and Chinese stimulus programs. While the spreading euro crisis has depressed German exports in these markets, the weakening euro has helped Germany to compensate for it by growing exports to the rest of the world. Record low interest rates owing to Germany's haven status delivered another euro-crisis boon. In 2012, German GDP stood above pre-crisis levels, the government budget was balanced again, while the country's external imbalance was-at 7 percent of GDP_-back near its pre-crisis peak.

Developments in 2012 have secured France a place in the opposite camp. Deep fault lines characterize the France-German partnership in the year of the $50^{\text {th }}$ anniversary of the “Treaty of Friendship." That France's government budget deficits of 4.6 percent in 2012 and 3.7 planned for 2013 seems to be only little in excess of the 3-percent mark does not describe the challenge France is facing. To begin with, the obligation is not a deficit below 3 percent of GDP but a balanced budget. More importantly, with private domestic demand collapsing in 2012, improving the government's financial balance can only be achieved through turning around the external position. Figure 2 above highlights what is at issue: France will need to engineer a relative wage disinflation of about 20 percent to get back to level with Germany. As the German economy, too, has stalled by yearend 2012, hopes for German wage inflation much above 2 percent seem optimistic. The German authorities, especially the Bundesbank, have made it clear that from their perspective, asking Germany for higher wage-price inflation to restore balance inside the currency union amounts to asking Germany to deliberately reduce its competitiveness (Weidmann 2012). Roughly speaking, this would imply a decade of flat wages in France, or a briefer period with actual wage declines. One way or another, restoring balance in this asymmetric fashion amounts to imposing debt deflation upon France (and other debtor countries).

Mindless austerity, wage restraint, and labor market liberalization worked for Germany — after a long delay of sickness—-because others behaved differently while the global economy was booming. With no offset provided regionally or globally, the consequences of this strategy when pursued jointly by a whole region can be observed in Europe today. In crisis countries, debt ratios are on the rise as a shrinking GDP undermines whatever little may be achieved in terms balancing the government's budget. The situation can only get worse for Euroland now that France, the number 2 economy, is joining this suicidal path for redemption in earnest. 
In particular, while the public finances of France and Germany have parted company since 2010, this situation is bound to deteriorate and drive a dangerous wedge between the two partners. IMF forecasts show Germany's debt ratio decline from its current 80 percent level while France's is supposed to peak at around 93 percent in 2014. Alas, the forecast for France is similarly ill-founded and misguided as earlier ones for Greece and others that failed to account for the collateral damages of austerity and structural reform. These overly optimistic forecasts also do not discount for the fact that deflationary rebalancing is pursued jointly union-wide.

And the whole endeavor may all prove futile anyway. For there is nothing that guarantees that Germany will not respond to its deteriorating competitiveness-which is inevitable for Euroland to rebalance! — with fresh attempts to "restore" its own competitiveness, which would further amplify the forces of debt deflation already at work. Euro weakening has brought some relief. But solving the euro crisis by running up external surpluses, while hoping for persistent euro undervaluation along the lines of Germany's mercantilist traditions, is not a reasonable option either. Euroland is still too large a share of the world economy for the German model to function, and the euro authorities have signed up for the G-20 Framework for achieving—not undermining—global balance.

The problem is that the German authorities cherish a highly confused notion of competitiveness. While it is obvious that the trade surpluses of one country cannot exist without the deficits of others, surpluses are judged inherently sound and morally virtuous, whereas deficits are seen as evidence of profligacy and a self-inflicted loss of competitiveness. There is a confused mingling of Euroland's external competitiveness, which is essentially a matter of the euro exchange rate and of intra-area competitiveness positions, which are essentially a matter of relative unit-labor cost trends.

Recall that Germany's motivation for stabilizing intra-European exchange rates was to reduce its vulnerability to movements in the dollar-deutschmark exchange rate. As the euro appreciated sharply since 2002, "the sick man of the euro" keenly "restored" its competitiveness by persistent wage repression. As a result, prior to the crisis, Germany's external surpluses were concentrated in Europe while Euroland's overall external position was balanced. Alas, the authorities did not grasp what I dubbed the "euro trilemma," that Germany cannot have all three, perpetual export surpluses, a no-transfer/no-bailout monetary union, and a "clean" independent central bank (Bibow 2012a). 
Even successfully restoring intra-area competitiveness- to avoid the abhorred but otherwise inevitable transfer union-would neither heal the fault lines between creditors and debtors nor dissipate the debt overhangs that are a legacy of Germany's ill-guided competitiveness crusade, only made worse by today's deflationary rebalancing strategy. The German authorities seem to believe that Germany could maintain extra-area trade surpluses even as intra-area rebalancing is achieved. While that has certainly been the outcome so far since the euro crisis has conveniently depressed the euro's external value, it must be an illusion for the hypothetical case of Euroland becoming as competitive as Germany (i.e., internally rebalanced) and the euro crisis getting resolved. Recall that France's hope for the euro was to have a joint external exchange rate policy that would reduce the area's dependence and vulnerability to external shocks, while Germany's hope was for protection against competitiveness losses inside Europe. It is an irony that Germany blocked French-style exchange rate policy in the Maastricht Treaty for fear that this would politicize the euro exchange rate and threaten the ECB's independence and its stability-oriented resolve but in the event of euro appreciation engineered the very outcome for Europe that Germany had hoped for the euro to prevent-just with Germany on the creditor side and with France on the debtor side of the equation.

\section{WILL THE ALLIANCE HOLD?}

No doubt all French hopes for the euro have been thoroughly frustrated. The euro regime neither provides for a common exchange rate policy applied to reducing the union's external vulnerability nor has it prevented the re-emergence of intra-area imbalances featuring huge German trade surpluses. At the current juncture, it is very clear that the euro has not ended France's subjection to asymmetric adjustment pressures. In fact, despite having been the one key country that faithfully stayed the course commonly committed to by the currency union members, France is today forced into a debt deflation process to restore its competitiveness visà-vis its unfaithful partner that reneged on the common euro stability norm. Moreover, confronted with a public finance situation, the impending sharp deterioration of which it is not solely responsible for, France is laboring under financing conditions that are significantly worse that Germany's - the ultimate culprit of the euro crisis. Going forward, France faces sharing the fate of other debtor countries in the union struggling with both debt legacies and adverse 
financing conditions that will burden their economic performance with a competitive disadvantage not only for a "lost decade" but also for a "lost generation."

In principle, members share mutual responsibility for the dismal failure of the euro regime. In practice, Germany, as the lead creditor nation, has largely dictated how the currency union has so far managed and tried to resolve the euro crisis. Essentially, Germany is upholding the myth of its own virtuous and exemplary conduct, commanding everyone else, including France, to "get their own house in order" and bear financial responsibility for their supposed failings. Lacking any sense of its own misconduct and chief responsibility for the euro crisis and resulting hardship, Germany demands that the union must honor the no-bail-out clause (Weidmann 2013).

In reality, a transfer union has emerged through the back door, at least to some extent. Originally, the so-called "bail-outs" (i.e., loans) facilitated through the European rescue facilities came not only with conditionality but also with onerous financing terms. This is gradually changing as financing costs are cut and maturities lengthened; although the unwarranted windfall gains enjoyed by Germany as supposed paragon and haven of safety are far from being properly shared. Following the Greek public debt restructuring of April 2012 that focused on private debt holders ("private sector involvement"), the official sector relief of December last year, including the agreed remittance of profits earned on Greek bonds acquired by the ECB under the Securities Market Program to Greece, had become necessary to resume IMF/euro area program disbursements. The "promissory notes" used by the Irish authorities in the context of resolving the Irish banking crisis are another case in point. In February 2013, the ECB acquiesced to the restructuring of these notes into long-term bonds, which avoided further short-term fiscal tightening due to the frontloaded repayment schedules of the original notes and will allow inflation to take care of a bigger part of the debt. Apparently, there is no longer any wish for Greece to exit the euro, while the wish for Ireland - the poster child for austerity-to succeed has grown stronger.

The use of the Eurosystem's balance sheet offers great flexibility and has also opened up another transfer gateway - even if, much to the Bundesbank's distress, this is contradicting traditional German monetary dogma. The infamous TARGET 2 imbalances are ultimately a fiscal liability of the creditor members, namely, in case of a euro breakup. At this point, their sheer magnitude reflects how big a favor the ECB has done especially for Germany by enabling German banks - and hence taxpayers - to call home their loans to the euro banking periphery at 
no loss. Overall, however, except for the acute case of Greece, implicit transfers remain limited so far and mainly address the flow issue, but not so much the stock issue that will divide creditors and debtors — and the France-German alliance-for a generation.

Facing these prospects, how much pain will it take to induce France to seriously contemplate the alternative: euro breakup? As Soros (2012) highlights, it matters a lot who leaves the euro. In case of a German exit, France (and any remaining euro partners) would get immediate relief both through a reduced (external) debt burden and restored competitiveness. German losses would be equally immediate as a strong new deutschmark would start with Germany plunging into deep recession while taking a large hit on its international investment position, too. A French exit would be more intricate, as debt reduction would need to take the form of outright default rather than currency depreciation. In any case, France is in the same boat as Spain in Italy, and the prospect of turning the dysfunctional Franco-German euro regime into a properly designed new "euro zone south" freed by German blockage might well become sufficiently attractive beyond some unknown pain threshold. At some point, debtors might also remember Keynes's quip, "If you owe your bank a hundred pounds, you have a problem. But if you owe a million, it has."

\section{CONCLUSION}

The euro was meant to lift the process of European integration-and the Franco-German partnership at its core - onto a new higher level. The ongoing euro crisis has revealed that the euro policy regime was ill-conceived from the beginning and remains deeply dysfunctional to this day. France and Germany held conflicting hopes and aspirations for the euro. The French saw it as a means to reduce the area's external vulnerability and perhaps even raise its global status, to prevent intra-area imbalances that had created asymmetric adjustment pressures for France in the past, and more generally as a way to restore equality among partners in the monetary domain. These hopes have been thoroughly disappointed. In terms of intra-regional imbalances, the area is in a similar position as at the time just before the Maastricht negotiations. It's just that, this time round, the prospects for any huge German fiscal stimulus, somewhat elevated German wage-price inflation, and exchange rate "realignments" are grim. Under the euro regime, Germany's partners are forced to undergo mindless austerity risking debt deflation. 
Germany's hopes for the euro focused on preventing competitiveness disruptions vis-àvis its European partners, a risk that stemmed from the deutschmark's rising reserve currency role. It is something of an irony that German wage restraint cum austerity delivered this very outcome, albeit with opposite signs, at a time when the euro's rising global popularity saw it surging on the exchanges. The problem is that the German authorities never quite understood that the success of German "stability orientation” depended on Germany's trade partners behaving differently, so that exporting the model to Europe would actually undermine its working. Nor did they understand that underbidding Germany's euro partners would make the much-dreaded transfer union an inevitable outcome.

The outcome is a disaster for the European project that will be difficult to overcome. It will be impossible to overcome without fundamental policy changes in Germany. Yet, much in contrast to the rest of Europe, Germany has so far had a fairly good crisis. Given the current state of German public opinion and the inability of the German body politic to grasp the fatal flaws in German economic policy, it is hard to see those fundamental policy changes happening in Germany.

Today, France is staring down the same abyss that Spain and Italy and others plunged into yesterday. Deepening fault lines are undermining the France-German alliance, which might soon turn into the ultimate euro battlefield. France's prospect of going through a deflationary process to restore competitiveness does not owe to France's own failings but to the fact that its “Treaty of Friendship" partner reneged on the golden rule of currency union. Since Germany took "competitive disinflation" to a new level under the euro, officially to "restore" its competitiveness albeit with Germany ending up with a gigantic external imbalance, France is now being forced to embrace "competitive austerity" to drive the deflationary euro rebalancing process. Breaking up the euro at its Franco-German heart by mutual consent could become the last resort in limiting the damages to the European project by bringing about the burden sharing that is needed to prevent the emergence of a new continental division of nations into creditordebtor classes. 


\section{REFERENCES}

Abdelal, R. 2007. Capital Rules. Cambridge: Harvard University Press.

Aldcroft, D. H. 1993. The European Economy 1914-1990, 3rd ed. London and New York: Routledge.

Bernholz, P. 1998. "Die Bundesbank und die Währungsintegration in Europa.” In Deutsche Bundesbank, ed. Fünfzig Jahre Deutsche Mark: Notenbank und Währung in Deutschland seit 1948. München: C. H. Beck.

Bibow, J. 2001. Comment. In J. Hölscher, ed. 50 Years of the German Mark. Houndmills and New York: Palgrave-Macmillan.

- 2003. "On the 'Burden' of German Unification." Banca Nazionale del Lavoro Quarterly Review 61(225): 137-69.

—. 2006. "The Euro Area Drifting Apart - Does Reform of Labor Markets Deliver Competitive Stability or Competitive Divergence?" In European Trade Union Confederation, ed. Structural Reforms and Macro-Economic Policy. Brussels: ETUC.

_ 2007. "Global Imbalances, Bretton Woods II, and Euroland's Role in All This." In J. Bibow and A. Terzi, eds. Euroland and the Global Economy: Global Player or Global Drag? Basingstoke: Palgrave-Macmillan.

—. 2012a. "The Euroland Crisis and Germany's Euro Trilemma." International Review of Applied Economics iFirst Article. October 9: 1-26. Previously published as Working Paper No. 721. Annandale-on-Hudson, NY: Levy Economics Institute of Bard College

_ 2012b. "At the Crossroads: The Euro and Its Central Bank Guardian (and Savior?)" Working Paper No. 738. Annandale-on-Hudson, NY: Levy Economics Institute of Bard College. Forthcoming in Cambridge Journal of Economics.

De Boissieu, C. and J. Pisani-Ferry. 1999. "The Political Economy of French Economic Policy in the Perspective of EMU." In B. Eichengreen and J Frieden, eds. Forging an Integrated Europe. Ann Arbor: University of Michigan Press.

Dyson, K. and K. Featherstone. 1999. The Road to Maastricht: Negotiating EMU. Oxford: Oxford University Press.

Eichengreen, B. S. 2007. The European Economy since 1945: Coordinated Capitalism and Beyond. Princeton: Princeton University Press.

Emminger, O. 1986. D-Mark, Dollar, Währungskrisen. Erinnerungen eines ehemaligen Bundesbankpräsidenten. Stuttgart: Deutsche Verlags-Anstalt.

Fitoussi, J.-P, E. Malinvaud, A. B. Atkinson, J. Flemming, and O. Blanchard. 1993. Competitive Disinflation: The Mark and Budgetary Politics in Europe. Oxford: Oxford University Press. 
Giersch, H., K.-H. Paque, and H. Schmieding. 1992. The Facing Miracle: Four Decades of Market Economy in Germany. Cambridge: Cambridge University Press.

Goodhart, C. A. E. 1998. "The Two Concepts of Money: Implications for the Analysis of Optimal Currency Areas.” European Journal of Political Economy 14: 407-32.

Goodman, J. B. 1992. Monetary Sovereignty: The Politics of Central Banking in Western Europe. Ithaca and London: Cornell University Press.

Gros, D. and N. Thygesen. 1998. European Monetary Integration: From the European Monetary System to Economic and Monetary Union, 2nd ed. New York: Longman.

Henning, C. R. 1994. Currencies and Politics in the United States, Germany, and Japan. Washington, DC: Institute for International Economics.

Hölscher, J. 1994. Entwicklungsmodell Westdeutschland: Aspekte der Akkumulation in der Geldwirtschaft. Berlin: Duncker \& Humblot.

Holtfrerich, C.-L. 1998. "Geldpolitik bei festen Wechselkursen (1948-1970).” In Deutsche Bundesbank, ed. Fünfzig Jahre Deutsche Mark: Notenbank und Währung in Deutschland seit 1948. München: C. H. Beck.

James, H. 2012. Making the European Monetary Union. Cambridge: Harvard University Press.

Johnson, P. A. 1998. The Government of Money - Monetarism in Germany and the United States. Ithaca and London: Cornell University Press.

Kaltenthaler, K. 1998. Germany and the Politics of Europe's Money. Durhum and London: Duke University Press.

Padoa-Schioppa, T. 2004. The Euro and Its Central Bank: Getting United After the Euro. Cambridge: MIT Press.

Reland, J. 1998. "France." In J. Forder and A. Menon, eds. The European Union and National Macroeconomic Policy. London and New York: Routledge.

Scherf, H. 1986. Enttäuschte Hoffnungen - vergebene Chancen: Die Wirtschaftspolitik der Sozial-Liberalen Koalition 1969-1982. Göttingen: Vandenhoeck \& Ruprecht.

Stephens, P. 2012. "Hollande Walks in the Shadow of De Gaulle." Financial Times, June 14. http://www.ft.com/intl/cms/s/0/81b7a26e-b4af-11e1-aa0600144feabdc0.html\#axzz2NEFrvPV6

Wallich, H. C. 1955. Triebkrafte des deutschen Wiederaufstiegs. Frankfurt am Main: F. Knapp

Soros, G. 2012. "The Tragedy of the EU and How to Resolve It." The New York Review of Books, September 27.

Weidmann, J. 2012. "Rebalancing Europe." Speech at the Chatham House, London, March 28. http://www.bis.org/review/r120329a.pdf 
— 2013. "Crisis Management and Regulatory Policy." Speech at the Walter Eucken Institute, Freiburg, February 11. http://www.bis.org/review/r130214c.pdf 